AGRICULTURE AND BIOLOGY JOURNAL OF NORTH AMERICA

ISSN Print: 2151-7517, ISSN Online: 2151-7525, doi:10.5251/abjna.2013.4.4.364.369

(C) 2013, ScienceHuß, http://www.scihub.org/ABJNA

\title{
Diesel oil utilizing bacteria associated with four Ghanaian soils
}

\author{
I.Y.D. Lawson ${ }^{1}$, J.K. Afenu ${ }^{1}$, E.K. Nartey ${ }^{1}$ and Jonathan Quaye ${ }^{2}$ \\ Soil Science Department ${ }^{1}$ and Animal Science Department ${ }^{2}$. \\ School of Agriculture, University of Ghana, \\ ABSTRACT
}

\begin{abstract}
The study was conducted in the laboratory with the aim to isolate, identify and assess the degradation potential of hydrocarbon utilizing bacteria in four Ghanaian soils sampled from different ecological zones. The bacteria were isolated using agar medium supplemented with diesel oil as the carbon source and isolates were then identified by comparing their biochemical and morphological characteristics with standards in Bergey's Manual of Determinative Bacteriology. To assess the degradation potential of the isolates, they were inoculated onto a sterilized filter paper contaminated with diesel oil for $72 \mathrm{hr}$ and followed by seed germination test. Results showed that six hydrocarbon utilizing bacterial genera, Bacillus, Staphylococcus, Enterobacter, Yersinia, Proteus, and Alcaligenes were present in the soils used. The dominant genus associated with all the soils used in the study was Bacillus. Results also showed that percentage seed germination improved for all the test crops when inoculated with the bacterial isolates. The most effective genus involved in the improvement of seed germination was Bacillus. The study clearly indicated that Ghanaian soils contain diverse bacterial genera capable of degrading and utilizing diesel oil as carbon source.
\end{abstract}

Key words: Contamination, diesel oil, germination, hydrocarbon utilizing bacteria, isolates

\section{INTRODUCTION}

The demand for petroleum as a source of energy and as a primary raw material for chemical industries in recent years has resulted in an increase in world production (Gutnick and Rosenberg, 1977). This dramatic increase in production, refining and distribution of crude oil has brought with it an ever increasing problem (Atlas and Barther, 1992) and a globally environmental pollutant (Plohl et al., 2002). Diesel oil, which is one of the major products of crude oil, constitutes a major source of pollution in our environment. With the combined dependence on diesel oil by some vehicles and generators, greater quantities are being transported over long distances.

The diesel oil is carcinogenic, mutagenic and it is a potent immunotoxicants posing a serious threat to human and animal health (Boonchan et al., 2000; Samanta et al., 2002). Diesel oil spills on agricultural land generally reduce plant growth. Suggested reasons for the reduced plant growth in diesel oil contaminated soils range from direct toxic effect on plants (Baker, 1982) and reduced germination (Udo and Fayemi, 1975) to unsatisfactory soil condition due to insufficient aeration of the soil because of the displacement of air from the space between the soil particles. The disposal methods of incineration or burial in secure landfills (USEPA, 2001; ITOPF, 2006) of petroleum products can become prohibitively expensive when the amounts of contaminants are large. This often results in cleanup delays while the contaminated soil continues to pollute groundwater resources if on land, and death of aquatic life if on waterways (Pye and Patrick, 1983), thus necessitating speedy removal of the contaminants. Oil spills, especially in soil contamination have prompted research on costeffective, environmentally benign cleanup strategies (Margesin and Schinner, 2001). Biodegradation of hydrocarbon-contaminated soils, which exploits the ability of microorganisms to degrade and/or detoxify organic contaminants, has been established as an efficient, economic, versatile and environmentally sound treatment (Mehrashi et al., 2003).

In 2007 crude oil was discovered in Ghana at Cape Three Point in the Western Region. In the closing days of 2010 when the country joined the league of oil producing countries and when the Jubilee Oil Field officially came on stream with the pumping of oil in commercial quantities, the country experienced oil spillage. On December 26, 2009, the country experienced its first spillage of about 584 barrels of 
low-based mud drilling fluid and the second mud spill of seven barrels occurred on March 23, 2010 (Ghanaian Daily Graphic, 2010). This frequency of spillage in the drilling field of Cape Three Point is of great concern. In a previous work, Lawson et al. (2012) reported that four Ghanaian soils sampled from different ecological zones showed signs of containing hydrocarbon utilizing microbes and had the potential to degrade diesel oil. It is therefore necessary to identify these hydrocarbon utilizing microbes, especially bacteria, in Ghanaian soils for future bioremediation. Hence, the study was conducted (i) to isolate and identify hydrocarbon utilizing bacteria in four Ghanaian soils, and (ii) to assess the diesel oil degrading potential of these bacteria.

\section{MATERIALS AND METHODS}

Isolation and identification of hydrocarbon utilizing bacteria: The soils used in this study were Toje series (Ferric Lixisol), Bekwai series ( Ferric Acrisol), Kokofu series (Eutric Nitosol), and Nyankpala series (Plinthic Acrisol). The Bekwai and Kokofu series were sampled from the semideciduous forest zone, Nyankpala series from the Guinea savanna zone and Toje series from the Coastal savanna zone of Ghana. These soils had no known history of diesel oil or crude oil product(s) contamination. The soils were contaminated with diesel oil at $10 \mathrm{~g}$ oil $/ \mathrm{kg}$ soil (air dry basis) and were maintained under same moisture content $(10 \%$; wt:wt basis). The contaminated soils were replicated three times and incubated in the laboratory under room temperature for ten days and soil samples were taken.

Ten (10) g of soil was sampled, tenfold serial dilution prepared; $1 \mathrm{~mL}$ of appropriate dilution was plated onto modified mineral salts agar medium of Mills et al. (1978) and modified vapour phase transfer technique of Okpokwasili and Amanchkwu (1988). The modified mineral salts medium contained $10 \mathrm{~g}$ $\mathrm{NaCl}, 0.42 \mathrm{~g} \mathrm{MgSO}{ }_{4} .7 \mathrm{H}_{2} \mathrm{O}, 0.29 \mathrm{~g} \mathrm{KCl}, 0.53 \mathrm{~g}$ $\mathrm{KH}_{2} \mathrm{PO}_{4}, 0.42 \mathrm{~g} \mathrm{NH}_{4} \mathrm{NO}_{4}$, and $15 \mathrm{~g}$ agar in $1 \mathrm{~L}$ distilled water (adjusted $\mathrm{pH}=6.8$ ). The modified vapour transfer technique involves spreading $0.5 \mathrm{~mL}$ of diesel (serving as carbon source) onto the mineral salts agar medium after setting and allowed the diesel oil to diffuse into the agar medium for $1 \mathrm{hr}$ before incubated at room temperature for 5 to 7 days. The colonies formed, considered hydrocarbon or diesel oil utilizing bacteria, were isolated and pure isolates were identified on the basis of their morphological and biochemical characteristics using the Bergey's Manual of Determinative Bacteriology.

Diesel oil utilizing potential of bacterial isolates: To assess the diesel oil degrading potential of the bacteria isolated, petri dishes containing sterilized filter papers were contaminated with diesel oil at 0,1 , $2,4,6,8$, and $10 \%$ and allowed seeds to germinate. The petri dish treated with $0 \%$ (ie. treated with only sterilized distilled water) served as the control. The test seeds, groundnut (Arachis hypogaea), cowpea (Vigna unguiculata), maize (Zea mays), and rice (Oryza sativa) were sterilized with $70 \%$ ethanol and 20 seeds were placed in each contaminated petri dish. The treatments were replicated three times, arranged in a complete randomized design in the laboratory and incubated at room temperature in a dark room for 3 days. The inhibitory concentration at $50 \%$ seed germination $\left(\mathrm{IC}_{50}\right)$ was determined for each test crop from the curves of percentage germination against various levels of diesel oil concentration. One (1) $\mathrm{mL}$ broth (approx. $1.5 \times 10^{5} \mathrm{cfu}$ ) of bacterial isolates was used to inoculate petri dishes containing sterilized filter papers contaminated with diesel oil at $\mathrm{IC}_{50}$, replicated three times, incubated for $72 \mathrm{hr}$ and followed by seed germination test.

\section{RESULTS AND DISCUSSION}

The morphological and biochemical characteristics of bacteria isolated from the soils are shown in Table 1. A total of six bacterial genera were identified in the four soils used. These genera were Bacillus, Staphylococcus, Enterobacter, Yersinia, Proteus, and Alcaligenes. Two genera were isolated from Bekwai series and three genera from Nyankpala and Toje series. The Kokofu series indicated a more diverse bacterial population with five genera. Staphylococcus was associated with Bekwai and Nyankpala series; Enterobacter and Alcaligenes were associated with only Kokofu series. The genus Yersinia was associated with Kokofu, Nyankpala and Toje series. Analyses also indicated that the genus Proteus was found in Kokofu and Toje series. The dominant bacterial genus was Bacillus. The savanna soils (Toje and Nyankpala) had two genera, Bacillus and Yersinia, in common; however, the semi-deciduous forest soils (Bekwai and Kokofu) had only Bacillus in common.

Several reports of bioremediation of petroleum contaminants by the action of Bacillus spp in extreme environments have been recorded. Ijah and Antai (1988) reported Bacillus spp as being the dominant 
bacteria of all the petroleum oil utilizing bacteria characterized from highly polluted soil samples. This is consistent with the present study since Bacillus was the most dominant bacterial isolate. There is growing evidence that isolates belonging to the Bacillus spp could be effective in cleaning oil spills
(Ghazali et al., 2004). Yersinia spp were also identified as bacteria involved in petroleum hydrocarbon degradation. In the work of Van-Hamme and Odumeru (2002), Yersinia spp was found to be among the dominant isolates growing on petroleum hydrocarbons in batch culture.

Table 1. Morphological and biochemical characteristics of the bacterial isolates.

\begin{tabular}{|l|c|c|c|c|c|c|c|c|c|l|}
\hline Sample & Slant & Butt & $\mathrm{H}_{2} \mathrm{~S}$ & $\mathrm{~S}$ & Indole & Gas & Shape & $\begin{array}{l}\text { Gram's } \\
\text { reaction }\end{array}$ & Motility & $\begin{array}{l}\text { Probable } \\
\text { organism }\end{array}$ \\
\hline $\mathrm{BE} 1$ & $\mathrm{R}$ & $\mathrm{R}$ & - & - & - & - & Rod & + & + & Bacillus spp \\
\hline $\mathrm{BE} 2$ & $\mathrm{Y}$ & $\mathrm{Y}$ & + & + & - & - & Cocci & + & + & $\begin{array}{l}\text { Staphylococcus } \\
\text { spp }\end{array}$ \\
\hline KO1 & $\mathrm{Y}$ & $\mathrm{Y}$ & + & - & - & - & Rod & - & + & Enterobacter spp \\
\hline KO2 & $\mathrm{Y}$ & $\mathrm{Y}$ & - & - & - & + & Rod & + & + & Proteus spp \\
\hline KO3 & $\mathrm{Y}$ & $\mathrm{Y}$ & - & - & - & + & Rod & - & + & Yersinia spp \\
\hline KO4 & $\mathrm{R}$ & $\mathrm{R}$ & - & - & - & - & Rod & + & + & Bacillus spp \\
\hline KO5 & $\mathrm{R}$ & $\mathrm{R}$ & - & - & - & - & Rod & - & - & Alcaligenes spp \\
\hline $\mathrm{NY1}$ & $\mathrm{R}$ & $\mathrm{R}$ & - & - & - & - & Rod & + & + & Bacillus spp \\
\hline NY2 & $\mathrm{Y}$ & $\mathrm{Y}$ & - & - & - & - & Rod & - & + & Yersinia spp \\
\hline NY3 & $\mathrm{Y}$ & $\mathrm{Y}$ & + & + & - & - & Cocci & + & + & $\begin{array}{l}\text { Staphylococcus } \\
\text { spp }\end{array}$ \\
\hline TO1 & $\mathrm{R}$ & $\mathrm{R}$ & - & - & - & + & Rod & + & + & Proteus spp \\
\hline TO2 & $\mathrm{R}$ & $\mathrm{R}$ & - & - & - & - & Rod & + & + & Bacillus spp \\
\hline TO3 & $\mathrm{Y}$ & $\mathrm{Y}$ & - & - & - & + & Rod & - & + & Yersinia spp \\
\hline
\end{tabular}

Key: $+=$ growth/presence, $-=$ No growth/ absence. $\mathrm{BE}=$ Isolates from Bekwai soil, $\mathrm{KO}=$ Isolates from Kokofu soil, $\mathrm{NY}=$ Isolates from Nyankpala soil and $\mathrm{TO}=$ Isolates from Toje soil. $\mathrm{R}=\mathrm{Red}$ and $\mathrm{Y}=$ Yellow.

Bacteria belonging to the Alcaligenes and Enterobacter genera are also widely reported to be implicated in petroleum hydrocarbon utilization. According to Chikere et al. (2009), bacteria of the genera Alcaligenes and Enterobacter had been isolated from petroleum oil contaminated soils. The presence of Staphylococcus spp in the present study also agrees with Adriano et al. (2007) who isolated Staphylococcus hominis from petroleum oil contaminated soils and Gomes et al. (2004) also isolated Staphylococcus aureus from a diesel contaminated soil.
The influence of diesel oil contamination on percentage germination of maize, rice, cowpea and groundnut in petri dish is shown in Table 2. The four test crops used in the germination test responded to diesel oil contamination. The pattern of responses in all the test crops to diesel contamination indicated that there was reduction in percentage germination with increased concentration of diesel oil. 
Table 2 . Germination \% of test crops at different diesel oil concentrations

\begin{tabular}{|l|c|c|c|c|c|c|c|}
\hline & & \multicolumn{2}{|l|}{} & & & & \\
\hline Test crop & Control & $1 \%$ & $2 \%$ & $4 \%$ & $6 \%$ & $8 \%$ & $10 \%$ \\
\hline & & & & & & & \\
\hline Maize & 100 & 85.00 & 75.00 & 66.67 & 61.67 & 55.00 & 48.00 \\
\hline & & & & & & & \\
\hline Rice & 100 & 94.61 & 92.81 & 83.91 & 80.34 & 77.67 & 77.67 \\
\hline & 100 & 88.33 & 68.33 & 46.67 & 40.00 & 33.3 & 31.67 \\
\hline Cowpea & 100 & 74.51 & 64.71 & 58.82 & 41.17 & 29.41 & 29.41 \\
\hline & & & & & & & \\
\hline Groundnut & & & & & & & \\
\hline
\end{tabular}

The control treatment (without contamination; 0\%) and $10 \%$ oil registered the highest and lowest percentage germination, respectively. In all the test crops, there was significant $(p<0.05)$ difference between the control and $1 \%$ level of contamination. Except for cowpea, there was no significant $(p>$ 0.05 ) difference between $1 \%$ and $2 \%$ oil levels of contamination. Groundnut and maize did not show any significant $(p>0.005)$ difference between 2 and $4 \%$ oil levels of contamination. Maize and groundnut recorded significant $(p<0.05)$ differences at $4 \%$ and $6 \%$ levels of contamination, whiles rice and cowpea did not. Maize and cowpea did not show any significant $(p>0.05)$ difference in germination between 4 and $10 \%$ oil levels of contamination even though there was decrease in percentage germination with increasing oil contamination. Groundnut and rice did not show significant $(p>$ 0.05 ) difference between 6 and $10 \%$ oil levels of contamination.

A similar effect of petroleum on germination was reported by Adam and Duncan (2002) and Njoku et al. (2009). They reported reduction in germination rate in several plant species caused by petroleum contamination. The decrease in germination as diesel concentration increased might not just be due to the contaminant concentration but also to the hydrocarbon type, plant species and reduction in oxygen transfer between the seed and the surrounding environment (Salanitro et al., 2004). The negative effect of diesel oil on germination with increased diesel oil concentration might also be due to their hydrophobic properties as reported by Adam and Duncan (2002) and Ogboghodo et al. (2004). Hydrocarbons may coat the seed, preventing or reducing gas and water exchange; they may also enter the seeds and alter the metabolic reactions and/or kill the embryo by direct toxicity (Adam and Duncan, 2002; Labud et al., 2007).

The inhibitory effect of diesel oil on germination in each test expressed as $\mathrm{IC}_{50}$ using polynomial model indicated that the legumes (cowpea and groundnut) were more sensitive to diesel oil contamination than the cereals (rice and maize) with rice being the most tolerant plant species among the test crops. The relatively high percentage germination in cereals could be due to the plastic-like testa (Muller et al., 2006) of the cereals which reduced the amount of diesel oil imbibed. The effect of inoculating the bacterial isolates on germination percentage at $\mathrm{IC}_{50}$ is represented in Table 3 . The inoculation enhanced the germination percentage of all the test crops.

The isolates that performed better were $\mathrm{BE} 1, \mathrm{KO} 4$, NY1 and TO2. From Table 1, these isolates were identified as Bacillus spp. Among these isolates, KO4 (isolated from Kokofu series) was generally considered to be the best isolate that enhanced germination. Besides, other isolates from the Kokofu series showed remarkable potential of degrading the diesel oil (Table 3). 
Agric. Biol. J. N. Am., 2013, 4(4): 364-369

Table 3. The effects of isolate inoculation on germination percentage of test crops at $I_{50}$

\begin{tabular}{|l|l|l|l|l|}
\hline $\begin{array}{l}\text { Isolate/Test } \\
\text { Crop }\end{array}$ & Maize & Rice & Cowpea & Groundnut \\
\hline BE1 & 77.71 & 71.56 & 56.78 & 66.15 \\
BE2 & 54.78 & 52.78 & 63.67 & 52.78 \\
Mean & 66.25 & $\mathbf{6 2 . 1 7}$ & $\mathbf{6 0 . 2 3}$ & $\mathbf{5 9 . 4 7}$ \\
\hline KO1 & 72.81 & 71.56 & 71.56 & 59.01 \\
KO2 & 63.44 & 66.15 & 52.78 & 46.92 \\
KO3 & 68.85 & 66.15 & 68.85 & 61.22 \\
KO4 & 77.71 & 77.17 & 77.71 & 59.01 \\
KO5 & 59.01 & 61.22 & 61.22 & 56.79 \\
Mean & 68.36 & $\mathbf{6 8 . 4 5}$ & 66.42 & $\mathbf{5 6 . 5 9}$ \\
\hline NY1 & 68.85 & 68.85 & 61.22 & 59.01 \\
NY2 & 63.44 & 57.00 & 52.78 & 59.01 \\
NY3 & 61.22 & 61.22 & 52.78 & 57.00 \\
Mean & 64.50 & $\mathbf{6 2 . 3 6}$ & $\mathbf{5 5 . 5 9}$ & $\mathbf{5 8 . 3 4}$ \\
\hline TO1 & 59.01 & 52.78 & 61.22 & 50.85 \\
TO2 & 66.15 & 61.22 & 66.15 & 61.22 \\
TO3 & 63.44 & 50.77 & 50.77 & 50.77 \\
Mean & $\mathbf{6 2 . 9 0}$ & $\mathbf{5 4 . 9 2}$ & $\mathbf{5 9 . 3 8}$ & $\mathbf{5 4 . 2 8}$ \\
\hline
\end{tabular}

In conclusion, the authors identified six bacterial genera; Bacillus, Staphylococcus, Enterobacter, Yersinia, Proteus, and Alcaligenes in the soils used in the present investigation. From the study the isolates have shown remarkable potential of degrading diesel oil. The dominant and most effective bacteria, Bacillus spp. can be isolated and packaged for future remediation of Ghanaian soils.

\section{REFERENCES}

Adam, G., Duncan, H. (2002). Influence of diesel on seed germination. Environmental Pollution 120: 363-370.

Adriano, P.M., Ana, P.A.G.K., Dejamira, F.A. (2007). Laboratory study on the bioremediation of diesel oil contaminated soil from a petrol station. Brazil Journal of Microbiology 38: 346-253.

Atlas R. M. and Barther J. (1992). Microbial ecology: fundamentals and applications, $4^{\text {th }}$ ed. Benjamin/Cummings Publishing, Menlo Park, Calif.

Boonchan, S., Britz, M.L. and Stanley, G.A. (2000). Degradation and mineralisation of high-molecular weight polycyclic aromatic hydrocarbons by defined fungal-bacterial cocultures. Applied Environmental Microbiology 7, 56-60.

Chikere, C.B., Okpokwasili, G.C. and Chikere, B.O. (2009). Bacterial diversity in tropical crude oil-polluted soil undergoing bioremediation. 8(11):2535-2540.

Ghazali, F.M., Rahman, R.N.Z.A. Salleh, A.B. and Basri, M. (2004). Biodegradation of hydrocarbons in soil by microbial consortium. International Biodeterioration and Biodegradation 54:61-67.

Gomes, R.V., Martins, S.C.S. and Melo, V.M.M. (2004). Produção de biossurfactante por Staphylococcus aureus isolado de uma amostra de petróleo pesado. IX ENAMA - Encontro nacional de Microbiologia Ambiental, Curitiba, Brazil.

Gutnick, D.L. and Rosenberg, E. (1977). Oil tankers and Pollution: a microbiological approach. Annual Review of Microbiology 341:379-396.

ljah, U.J.J. and Antai, S.P. (1988). Degradation and Mineralization of crude oil by bacteria. Nigeria Journal of Biotechnology. 5:79-86. 
International Tanker Owners Pollution Federation Limited (ITOPF) (2006). Disposal of Oil and Debris. In: Response Strategies. http://www.itopf.com/index.html.

Labud, V., Garcia, C. and Hernandez, T. (2007). Effects of hydrocarbon pollution on the microbial properties of a sandy and clay soils. Chemosphere 66: 1863-1871.

Lawson, I.Y.D., Nartey, E.K., Darko, D.A., Ockrah and Tsatsu, D. (2012). Microbial degradation potential of some Ghanaian soils contaminated with diesel oil. Agriculture and Biology Journal of North America. 3(1):1-15

Margesin, R. and Schinner, F. (2001). Bioremediation (natural attenuation and biostimulation) of diesel-oil contaminated soil in an Alpine glacier skiing area. Applied Environmental Microbiology 67(7):3127-3133.

Mehrashi, M.R., Haghighi, B., Shariat, M., Naseri, S. and Naddafi, K. (2003). Biodegradation of petroleum hydrocarbons in soil. Iranian Journal of Public Health 32(3): 28-32.

Mills A.L, Breuil C, Colwell R.R (1978). Enumeration of petroleum degrading marine and estuarine microorganisms by the most probable method. Can. J. Microbiol. 24:552-557.

Muller, K., Tintelnot, S. and Leubner-Metzger, G. (2006). Plant and cell Physiology. Oxford University Press, United Kingdom, 864-877.

Njoku, K.L., M.O. Akinola and B.G. Taiwo. (2009). Effect of gasoline diesel fuel mixture on the germination and growth of Vigna unguiculata (cowpea). Journal of Environmental Science and Technology. Vol 3 (12): 466-471.
Okpokwasili GC, Ananchukwu SC (1988). Petroleum Degradation by Candida species. Environ. Int. 14: 243247.

Ogboghodo IA, Iruaga EK, Osemwota JU (2004). An assessment of the effects of crude oil pollution on soil properties, germination and growth of maize using two crude oil types- forcados light and escravos light. Eviron. Monitor. Assess. 96:143-152.

Plohl K, Leskovsek H, Bricelj M (2002). Biological degradation of motor oil in water. Acta Chim. Slovenica. 49: 279-289.

Pye VI, Patrick R (1983). Groundwater contamination in the United States. Science. 221: 713- 718.

Salanitro JP, Dorn PB, Huesemann MH, Moore KO, Rhodes, IA, Jackson LMR, Vipond TE, Western MM, Wisniewski HL (2004). Crude Oil Hydrocarbon Bioremediation and Soil Ecotoxicity Assessment. Environ. Sci. Technol. 31: 1769-1776.

Samanta KS, Singh OV, Jain RK (2002). Polycyclic aromatic hydrocarbons: environmental pollution and bioremediation. Trends Biotechnol., 20(6): 243-248.

Udo EJ, Fayemi AA (1975). The effects of oil pollution of soil on Germination, growth and nutrient uptake of corn. J. Environ Qual. 4: 537-540.

United States Environmental Protection Agency (USEPA) (2001). Understanding Oil Spills and Oil Spill Response. http://www.fundyforum.com/profile archives/profile3.ht $\underline{\mathrm{ml}}$.

Van-Hamme J.D. and Odumeru J.A (2002). Community dynamics of a mixed-bacterial culture growing on petroleum hydrocarbons in batch culture. Can. J. Microbiol. 46(5): 441-450. 